\title{
Teacher and Student Perspectives on Written Feedback
}

\section{Kent Jones}

\section{Ritsumeikan Asia Pacific University \\ Kevin Tang \\ Ritsumeikan Asia Pacific University}

\section{Reference Data:}

Jones, K., \& Tang, K. (2019). Teacher and student perspectives on written feedback. In P. Clements, A. Krause, \& P. Bennett (Eds.), Diversity and inclusion. Tokyo: JALT.

The results of teacher and student surveys regarding beliefs about feedback on student writing are examined. 57 English language teachers in Japan and 317 EFL students at a Japanese university were surveyed to answer the following: (a) How much time do teachers spend explaining their feedback systems and are students satisfied with it? (b) What types of feedback (Ellis, 2008) do teachers and students prefer and why? and (c) Do students believe their teachers' feedback helps them avoid similar mistakes in future pieces of writing? Results showed the majority of students felt teachers spent enough time explaining their feedback system, but a sizeable minority wanted more explanation. Both teachers and students preferred metalinguistic feedback, but students preferred explanations to correction symbols. Despite their teachers' corrections, most students felt that they would make the same mistakes in later pieces of writing. Implications for both classroom practice and further research are discussed.

本稿は、ライティングにおけるフィードバックに対する考えについて英語教員 (57名) と大学生 (317名) を対象に調査した 結果である。調査された質問項目は、1）教員がフィードバックの方法について説明した時間及び説明に対する学習者の満足 度、2）教員と学習者がどのようなフィードバック (Ellis, 2008) を好むかとその理由、3) 学習者はフィードバックが同じ誤りを防 ぐことにつながると考えているか、の3点である。結果、1）に関しては、多くの学習者が現状で十分だとする一方、更なる説明を 求める者も少数いた。2）は両者とも、メタ言語でのフィードバックを好む傾向にあるが、学習者は訂正記号よりも説明を好む 傾向にある事がわかった。また教員の訂正にも拘らず、学習者は同じ誤りを繰り返しそうだと感じている事も明らかとなった。 本調査をふまえ、ライテイング授業での効果的なフィードバック方法についても言及する。 oth educators and students consider written feedback to be essential in helping students improve their writing. However, the extent to which they agree on how feedback is administered needs further exploration. Teachers employ a number of methods to give feedback on student writing such as correcting errors directly, supplying explanations to encourage self-correction, or simply underlining the error, placing the responsibility for self-correction directly on the student. Teachers and students have different perspectives in terms of their awareness of the pedagogical value of each correction type and the amount of time they are willing to spend indicating or identifying and addressing errors.

Teachers understand their feedback systems very well. The process of giving feedback allows them to deeply familiarize themselves with these systems. Students, on the other hand, are much less familiar with the systems. Therefore, consideration about how well they understand the teacher's feedback system and how it can help them improve their writing is key. It is important to consider how much time teachers spend explaining their system and how well students feel they understand it.

There is also the question of uptake: the extent to which students recognize their errors and how it can lead to students not making the same error in the future. Feedback should help students not only make revisions on one piece of work but also feel confident that they will not make the same error in other pieces of writing.

\section{Past Studies on Feedback Types and Preferences}

\section{Different Feedback Types}

Ellis (2008) explained five main feedback types: direct corrective feedback, indirect corrective feedback, metalinguistic feedback, focused feedback, and unfocused feedback. Direct corrective feedback refers to interventions through which the teacher provides the student with the correction. Indirect feedback involves the teacher simply indicating the error, usually by underlining or circling it. When giving metalinguistic 
feedback, the teacher provides a brief explanation of the type of error in the form of a correction symbol or a brief explanation of what the student should do. In giving focused feedback, teachers only indicate one or two types of errors and leave others uncorrected. Unfocused feedback, on the other hand, involves the teacher giving feedback on all errors in the student's work. According to the results of a number of studies, focused feedback is highly beneficial to students (Bitchener, 2008; Bitchener \& Knoch, 2008; Farrokhi \& Sattarpour, 2011; Sheen, 2007; Sheen, Wright, \& Moldowa, 2009; Shintani \& Ellis, 2013) Nonetheless, as McGrath (2015) pointed out, its effectiveness may be questionable in courses in which students only produce two or three pieces of writing in a semester. In the English program in which this study was conducted, teachers must employ an unfocused feedback system in order to meet the program's specified requirements.

\section{Teacher Perspectives According to Previous Studies}

A number of studies have found that teachers favored metalinguistic and indirect feedback. When asked to elaborate, many participants responded that they felt that these types promoted self-correction because they got students to reflect on their errors and actively make corrections (Amrhein \& Nassaji, 2010; Diab, 2005). Some teachers also felt direct correction was too time-consuming (Amrhein \& Nassaji, 2010). In addition, teachers tended to value feedback on content and organization more than correction of grammatical and lexical mistakes (Amrhein \& Nassaji, 2010; Diab, 2005). This was not, however, true of teachers in all of the studies. Some studies reported a greater focus on the direct correction of grammar errors. However, the teachers in these studies felt that metalinguistic feedback was the second most important category (Furneaux, Paran \& Fairfax, 2007; Lee, 2008). Thus, although teachers did not always agree about the type of feedback they valued most or the errors they felt were most in need of treatment, they also felt that students should be encouraged to identify and correct their mistakes.

\section{Student Perspectives According to Previous Studies}

Most studies related to student perspectives on written feedback have reported that students prefer direct feedback. Amrhein and Nassaji (2010) found that most participants disliked indirect and even metalinguistic feedback because they felt these did not explain the errors well enough. They valued metalinguistic feedback only when it was accompanied by a direct correction. Elwood and Bode (2014) also found that students had a clear preference for detailed direct feedback over indirect feedback, although they appreciated direct corrections that were accompanied by a metalinguistic explanation over direct correction alone. Lee in two different studies $(2005,2008)$ observed that students preferred direct feedback with detailed explanations. However, in the 2008 paper, Lee also made the suggestion that the teacher-centered nature of the feedback, in which teachers supplied the answers and explanations for the students, made students passive and dependent. Indeed, despite student demands for more feedback and explanation, students were often found to not act on their feedback. Elwood and Bode (2014) observed that although students expected extensive corrections, they did little to correct their mistakes even when revisions were required.

\section{The Importance of Explanation}

The tendency for students not to act on their corrections should not be attributed to a lack of motivation alone, but may be caused by a lack of understanding of how to use their teachers' feedback to improve their writing. Elwood and Bode (2014) suggested that teachers needed to be more explicit about their expectations and give students clear training on how to utilize their feedback. In a study that actually put this recommendation into practice, Plonsky and Mills (2006) found that student attitudes towards indirect and metalinguistic feedback improved after teachers explicitly explained their feedback approach.

\section{Usefulness of Feedback}

Some researchers have questioned the usefulness of feedback, even when both teachers and students are diligent in following the feedback system. Truscott (1996) argued that corrective feedback could only be considered effective when it led to improvement: not only in revised drafts, but in subsequent pieces of writing. Since that claim was made, numerous studies have shown that corrective feedback can have positive and lasting effects. However, these have all dealt with focused feedback and have centered around improving a single language point (Bitchener, 2008; Bitchener \& Knoch, 2008; Farrokhi \& Sattarpour, 2011; Sheen, 2007; Sheen, Wright, \& Moldowa, 2009; Shintani \& Ellis, 2013). Far fewer studies have made similar claims about unfocused feedback, though Van Beuningen, De Jong, \& Kuiken, (2012) found that long term gains in grammatical accuracy, content, and organization could also be made through unfocused feedback.

\section{Methodology}

Research Questions

Based on the key themes described above, this study was aimed at answering three research questions. The first research question was designed to explore claims by some 
researchers that students respond better to feedback if teachers take time to explain the feedback system used (Elwood \& Bode, 2014; Plonsky \& Mills, 2006). The second research question refers to the main four feedback types outlined by Ellis (2008). We seek to discern the types of feedback used most often by teachers and considered most useful by students. Finally, the last question addresses the claim by Truscott (1996) that feedback can only be effective when it leads to long-term improvement by looking at how students felt their teachers' feedback helped them improve.

RQ1. How long do teachers spend explaining their feedback systems? Do students feel they need more explanation?

RQ2. Which types of feedback do teachers and students prefer, and do these preferences differ?

RQ3. Do students feel that their teachers' feedback helps them not make the same mistakes in later pieces of writing?

\section{Surveys}

The data analyzed in this project resulted from two surveys: one administered to 57 teachers and one administered to 317 students in a university in Japan. An account of the teacher survey data was previously published in the APU Journal of Language (Jones \& Tang, 2017).

\section{Teacher Survey Participants}

Teachers who completed the survey consisted of colleagues and former colleagues of the authors. The prospective participants were contacted with an email containing a link to an electronic survey created on Google Forms. Of the 64 teachers contacted to complete the survey, 57 responded: a response rate of $89 \%$. In order to make the data from the teacher and student surveys comparable, nine of these respondents were removed because they did not work in the institution where the student survey took place. In the end, the data from 48 teachers' responses are reported.

\section{Student Survey Participants}

The student participants who completed the survey were students at all levels of the English program at a medium-sized private university in Japan. Students in this university take English courses at the elementary (CEFR A1), pre-intermediate (CEFR A2), intermediate (CEFR B1), and upper intermediate (CEFR B1+) levels for a total of
2 years of study. Students were requested to complete the survey voluntarily on the university's learning management system. Of the 563 students enrolled in the program, 317 responded: a response rate of $56 \%$. This survey was piloted with a class of 20 intermediate (CEFR B1) students. As the students were able to understand the questions, no revisions were made. The pilot responses were then included in the total.

\section{Teacher Survey Design}

The teacher survey consisted of three types of questions: questions about the amount of time teachers spent explaining their feedback system, questions regarding their preferred corrective feedback types, and questions aimed at learning the extent to which teachers felt students were able to understand their feedback system (see Appendix B). As teachers were expected to be fairly knowledgeable about written corrective feedback, questions were expressed in explicit terms.

\section{Student Survey Design}

The student survey explored the same themes as the teacher survey but was revised to take the unique perspective of students into account (see Appendix A). For example, students were asked about both the amount of time their teachers spent explaining their feedback system and if they felt that they needed more explanation time. Regarding the questions about feedback type preferences, students could not be expected to understand explicit questions about their preferred types. As a result, these preferences were elicited implicitly by giving them examples of feedback types and asking them, on a 5-point Likert scale, the extent to which they felt them to be helpful. Items were also given in both English and Japanese to ensure understanding. The student survey also contained a section that elicited the extent to which they felt their teachers' feedback helped them correct future writing.

\section{Results}

The results will be discussed in the order of data collection, alternating between teacher and student surveys. As illustrated in Figure 1, the majority of teachers spent less than 30 minutes explaining their feedback system and a comparable number spent less than 10 minutes. A much smaller number allotted more than 30 minutes and an equally small number did not spend any time at all explaining the feedback system. 


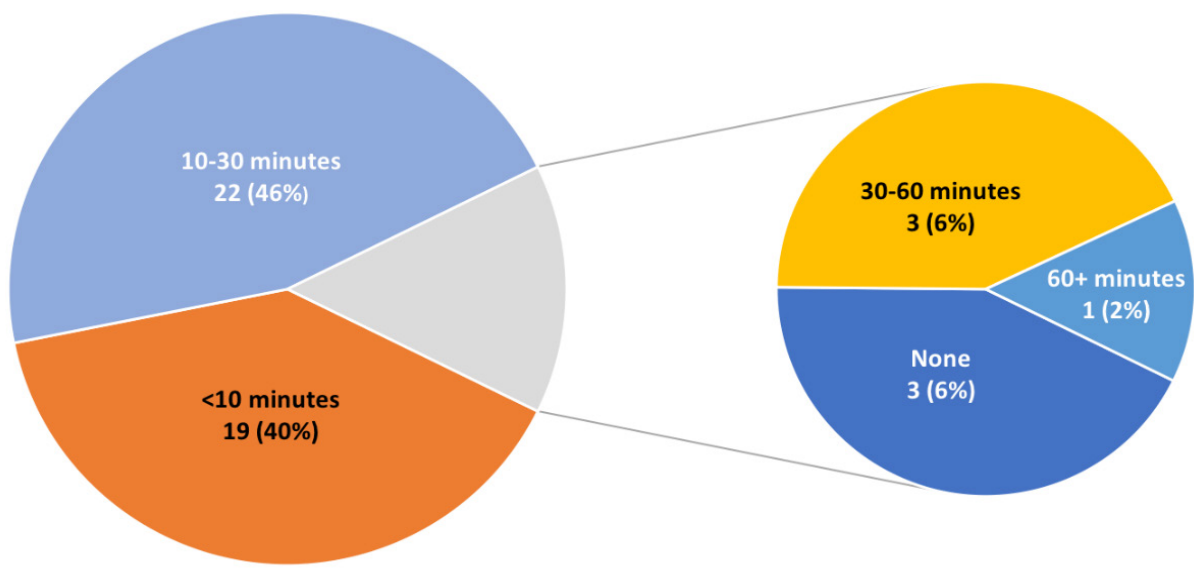

Figure 1. Amount of time teachers used to explain feedback system $(n=48)$.

As shown In Figure 1, 46\% of teachers spent 10-30 minutes explaining their feedback systems. As can be seen in Table 1, nearly the same percentage of students $(47 \%)$ reported that their teachers used that same range of time. When asked whether or not they desired more explanation time, only 90 (31\%) of the 293 student respondents indicated that they did. This student minority can be broken down as follows: When no explanation time was given (10 respondents), five wanted more time devoted to explanations; when the amount of time was less than 10 minutes (86 respondents), 29 desired more; when explanations were in the 10-30 minute range (137 respondents), 43 were eager for clarification. As more time was devoted to explanations, the percentage of students wanting even more decreased, as is evident in the 30-60 minute span when only 10 (of 44 respondents) wanted to know more; of those receiving 60 minutes or more of explanation, only 3 (of 16 respondents) wished to have additional information.
Table 1. Student Report of Teacher Explanation Time and the Percentage of Students Who Felt They Wanted More Explanation $(n=293)$

\begin{tabular}{lcccc}
\hline $\begin{array}{l}\text { Amount of } \\
\text { explanation time } \\
\text { received }\end{array}$ & \multicolumn{2}{c}{ Respondents } & \multicolumn{2}{c}{$\begin{array}{c}\text { Wanted more explanation } \\
\text { time }\end{array}$} \\
\cline { 2 - 5 } None & Number & Percentage & Number & Percentage \\
\hline <10 minutes & 10 & $3.41 \%$ & 5 & $50.00 \%$ \\
10-30 minutes & 86 & $29.35 \%$ & 29 & $33.72 \%$ \\
30-60 minutes & 137 & $46.76 \%$ & 43 & $31.39 \%$ \\
60+ minutes & 44 & $15.02 \%$ & 10 & $22.73 \%$ \\
Total & 16 & $5.46 \%$ & 3 & $18.75 \%$ \\
\hline
\end{tabular}

As can be seen in Table 2, the majority of the 48 teachers preferred metalinguistic feedback and indirect explanations, which is in accordance with teacher preferences in prior studies regarding metalinguistic feedback. Metalinguistic feedback featuring correction symbols was more often used by 30 of the instructors but was not nearly as popular as metalinguistic explanations (36). Surprisingly, only 21 preferred indirect feedback. However, the least popular mode of feedback for teachers was direct feedback, which only 20 claimed to use.

Table 2. The Types of Feedback Most Commonly Used by Teachers $(n=48)$

\begin{tabular}{lcc}
\hline Type of feedback used by teacher & Number & Percentage \\
\hline Correction symbols & 30 & $63 \%$ \\
Indirect explanations & 36 & $75 \%$ \\
Direct feedback & 20 & $42 \%$ \\
Indirect feedback & 21 & $44 \%$ \\
\hline
\end{tabular}

Note. More than one answer was possible.

The variables listed in Table 3 are the outcomes from questions on a 5-point Likert scale in which students were given an example of a type of feedback and were asked to rate its 
usefulness from 1 (not useful at all) to 5 (very useful). The number of students (out of 317 in total) who answered the questions posed by the five survey items averaged 314.8 or $99.3 \%$. Students' opinions about the feedback system their teachers used did not vary greatly: mainly neutral (3) and helpful (4). Indirect explanations had the highest mean (4.057) with a small standard deviation: 315 respondents found that system to be helpful. In fact, the remaining three feedback systems were all deemed closer to being helpful than neutral by the students, without a wide variance, as seen by their respective standard deviations. Indirect feedback had 313 respondents, with a mean of 3.997 and a small standard deviation Direct feedback had a total of 315 responses with a mean of 3.790 but a slightly higher standard deviation. In comparison, although correction symbols also had 315 respondents, its mean was just slightly lower as well as its standard deviation. When asked if their teachers' comments would be helpful in avoiding the same errors in future writing, 316 participants were rather neutral with a slightly higher standard deviation.

Table 3. Student Opinions on the Various Types of Feedback Received $(n=317)$

\begin{tabular}{lccc}
\hline Correction system & Number & Mean & SD \\
\hline Correction symbols & 315 & 3.755 & 0.938 \\
Indirect explanations & 315 & 4.057 & 0.932 \\
Indirect feedback & 313 & 3.997 & 0.982 \\
Direct feedback & 315 & 3.790 & 1.086 \\
How teacher feedback prevents errors in general & 316 & 3.028 & 1.102 \\
\hline
\end{tabular}

Note. Answers were on a 5-point Likert scale in which students were given an example of a type of feedback and were asked to rate its usefulness from 1 (not useful at all) to 5 (very useful).

\section{Discussion and Practical Implications}

Contrary to the recommendations of Elwood and Bode (2014) and Plonsky and Mills (2006) to increase the amount of time spent explaining feedback systems, the majority of teachers and students felt that the amount of explanation they gave or received was sufficient. This is surprising, as most teachers and students reported only 6 to 10 minutes of explanation time. Indeed, a sizeable minority of students indicated that they would like to receive more explanation. Thus, even though many students may have said that they did not need extra explanation, it would be helpful for teachers to make such information available to students who want it, in the form of a document or a video lecture.

In terms of preferred feedback methods, it was found that both teachers and students showed preferences for metalinguistic explanations and direct correction. Although this result is similar to past studies in regard to student perceptions (Amrhein \& Nassaji, 2010; Elwood \& Bode, 2014; Lee, 2005, 2008), it runs contrary to previous reports that teachers felt direct correction was too time-consuming and did not facilitate self-correction (Amrhein \& Nassaji, 2010; Diab, 2005). Moreover, the student respondents in the current study showed a more positive attitude to self-correction than did participants in previous studies. Conversely, teachers expressed a reluctance to give indirect feedback, most likely because they felt that they were not giving students enough instruction. Finally, teachers considered correction symbols to be useful, but students considered them to be the least desirable feedback type, possibly because students felt remembering the codes was difficult and troublesome in comparison to teachers giving them detailed metalinguistic explanations.

These findings show that students may be more flexible in their feedback preferences than earlier studies have suggested. Although students reacted positively to examples of direct correction, they also showed positive attitudes towards indirect correction. Moreover, their positive attitudes towards metalinguistic explanation but less positive attitudes towards correction symbols indicate that though they want to have their errors explained to them, they are not interested in memorizing symbols. Of course, writing out metalinguistic explanations for every error would be a time-consuming task for teachers. However, with new feedback technology, such as the "quick note" feature on Turnitin, it is possible for teachers to create a detailed and standardized digital list of comments that can be used to indicate student errors just as quickly as writing shorthand correction symbols on paper.

In regard to the comprehensibility of the feedback, though it was found that both teachers and students agreed that they were able to understand the feedback well enough to make revisions, students were less confident that they would stop making the same errors in future writing. Indeed, most students felt that they would continue to make the same mistakes, with only a small number believing that corrections helped them avoid making similar subsequent mistakes. The fact that students have this feeling of uncertainty about their writing improvement also makes a strong case for more focused feedback.

\section{Limitations and Further Research}

One of the limitations of this study was the indirect nature of the survey question design. Because students were not expected to understand the feedback typology used in this study, they were not clearly asked about their preferences for different modes of feedback 
for each category of error (content, organization, vocabulary, and grammar). If replicated, a more detailed, qualitative study focusing on student perceptions of feedback in a number of error categories would be useful.

Although it is interesting that the majority of participants felt that their teachers' corrections did not help them to avoid making the same errors in future writing, this information is incomplete because teachers were not asked their opinions about this. It would be useful to see if teachers themselves agreed. Moreover, this study has only explored general teacher and student perceptions about feedback. An experimental longitudinal study objectively investigating student cognitive processes in receiving corrections to an initial piece of writing and how those carry over into the formulation of new pieces of writing would be a next step in understanding the processes at work and determining an effective and practical way to develop student accuracy and proofreading ability.

Despite focused feedback being a popular topic in recent studies, opinions regarding this feedback type were not explored because it is not currently being used at the university where this study took place. In the experimental longitudinal study proposed above, tasks involving focused and unfocused feedback types could also be observed.

\section{Conclusion}

In regard to the first research question inquiring about the amount of time teachers spent explaining their feedback system and the level of students' satisfaction with it, these findings show that the majority of teachers and students felt the brief time spent explaining the feedback system was sufficient. Nonetheless, there was a sizeable minority of students who believed that they could have received more explanation. This indicates the need for teachers to make such explanations available, if not during class time, at least in the form of supplementary resources.

Concerning the second research question about the types of feedback that teachers and students preferred, it was also found that they were largely in agreement. There was a general belief that metalinguistic explanation was important. Nonetheless, most students felt that this should be given as a clear explanation as opposed to a system of codes. Current technology, such as digital feedback suites like Turnitin, makes it possible for teachers to provide this type of detail while retaining the efficiency of a feedback code system. Also, it was found that although students reported finding direct feedback useful, no doubt because it provided a clear explanation for their errors, they also had a positive view of indirect feedback, indicating that they understood the importance of self-correction.
Finally, to address the last research question about students' feelings that teacher feedback helped them avoid the same mistakes in future writing, students indicated that although teachers corrected their mistakes, they were likely to make the same errors in subsequent writing. This is an issue that needs to be investigated in more detail. It also indicates that more needs to be done to attempt to integrate focused feedback, which recent studies have suggested as a way to circumvent this problem, into regular classroom practices. An experimental longitudinal study examining both student cognitive processes in revising their writing and formulating new pieces of writing would be a useful continuation of the present study.

\section{Bio Data}

Kent David Jones is a lecturer at the Center for Language Education at Ritsumeikan Asia Pacific University, Beppu, Japan. He has taught ESL at universities and colleges in Canada as well as EFL in universities in Japan. His curriculum development and research work are largely related to writing, particularly feedback. <kent.jones.apu@gmail.com>

Kevin Tang worked first in comic book publishing then multimedia in New York City. He taught English as a 5-year JET ALT then as a lecturer at the English Education Center at Ehime University before joining Ritsumeikan APU. He is ardent about exploring augmented reality technology as a pedagogical tool.<kev.tang.apu@gmail.com>

\section{References}

Amrhein, H., \& Nassaji, H. (2010). Written corrective feedback: What do teachers and students prefer and why? Canadian Journal of Applied Linguistics, 13(2), 95-127. Retrieved from https:// eric.ed.gov/?id=EJ944129

Bitchener, J. (2008). Evidence in support of corrective written feedback. Journal of Second Language Writing, 17(2), 103-118.

Bitchener, J., \& Knoch, U. (2008). The value of a focused approach to written corrective feedback on ESL student writing. Journal of Second Language Writing, 9, 227-258.

Diab, R. L. (2005). Teachers' and students' beliefs about responding to ESL writing: A case study. TESL Canada Journal, 23, 28-43. https://doi.org/10.18806/tesl.v23i1.76

Ellis, R. (2008). A typology of written corrective feedback types. ELT Journal, 63(2), 97-107. https:// doi.org/10.1093/elt/ccn023

Elwood, J. A., \& Bode, J. (2014). Student preferences vis-à-vis teacher feedback in university EFL writing classes in Japan. System, 42, 333-343. https://doi.org/10.1016/j.system.2013.12.023 
Farrokhi, F., \& Sattarpour, S. (2011). The effects of focused and unfocused written feedback on the grammatical accuracy of Iranian ESL learners. Theory and Practice in Language Studies, 1(12) 1797-1803. https://doi.org/10.4304/tpls.1.12.1797-1803

Furneaux, C., Paran, A., \& Fairfax, B. (2007). Teacher stance as reflected in feedback on student writing: An empirical study of secondary school teachers in five countries. IRAL-International Review of Applied Linguistics in Language Teaching, 45(1), 69-94. https://doi.org/10.1515/ iral.2007.003

Jones, K., \& Tang, K. (2017). Teacher beliefs and practices about administering corrective feedback on student writing. APU Journal of Language Research, 3, 72-93.

Lee, I. (2005). Error correction in the L2 writing classroom: What do students think? TESL Canada Journal, 22(2), 1-16. https://doi.org/10.18806/tesl.v22i2.84

Lee, I. (2008). Student reactions to teacher feedback in two Hong Kong secondary classrooms. Journal of Second Language Writing, 17(3), 144-164. https://doi.org/10.1016/j.jslw.2007.12.001

McGrath, D. (2015). Research into corrective written feedback. OnCue Journal, 8(2), 96-106. Retrieved from https://jaltcue.org/files/OnCUE/OCJ8.2/OCJ8.2_pp106_116_McGrath.pdf

Plonsky, L., \& Mills, S.V. (2006). An exploratory study of differing perceptions of error correction between a teacher and students: Bridging the gap. Northern Arizona University Applied Language Learning, 16, 55-77.

Sheen, Y. (2007). The effect of focused written corrective feedback and language aptitude on ESL learners' acquisition of articles. TESOL Quarterly, 41(2), 255-283. https://doi. org/10.1002/j.1545-7249.2007.tb00059.x

Sheen, Y., Wright, D., \& Moldowa, A. (2009). Differential effects of focused and unfocused written correction on the accurate use of grammatical forms by adult ESL learners. System, 37(4), 556569. https://doi.org/10.1016/j.system.2009.09.002

Shintani, N., \& Ellis, R. (2013). The comparative effect of direct written corrective feedback and metalinguistic explanation on learners' explicit and implicit knowledge of the English indefinite article. Journal of Second Language Writing, 22(3), 286-306. https://doi.org/10.1016/j. jslw.2013.03.011

Truscott, J. (1996). The case against grammar correction in L2 writing classes. Language Learning, 46, 327-369. https://doi.org/10.1111/j.1467-1770.1996.tb01238.x

Van Beuningen, C., De Jong, N. H., \& Kuiken, F. (2012). Evidence on the effectiveness of comprehensive error correction in second language writing. Language Learning, 62(1), 1-41. https://doi.org/10.1111/j.1467-9922.2011.00674.x

\section{Appendix A}

Corrective Feedback for Writing Beliefs and Practices Survey (for Students)

1. How much class time did your teacher spend explaining his/her feedback system for writing? / どのくらいの時間、先生がフィードバックシステムについてを説明しますか?

$$
\begin{aligned}
& \text { - } \text { None } \\
& \text { - }<10 \text { minutes } \\
& \text { - } 10-30 \text { minutes } \\
& \text { - } 30-60 \text { minutes } \\
& \text { - } 60+\text { minutes }
\end{aligned}
$$

2. Do you feel that your teacher should spend more time explaining their feedback system for writing? / 先生のフィードバックシステムをもつと詳しく説明したほうが良いと思い ますか?

- No/いいえ。

- Yes, a little more / はい、もう少し説明したほうがいいと思う。

・ Yes, much more time /はい、もっと時間をかけて説明したほうがいいと思う。

3. To what extent do you agree with this statement: Correction symbols (for example, writing "VT" to indicate a verb tense error) every time I make a mistake are helpful because they lead me to making corrections myself. / どの程度当てはまりますか: コレク ションシンボルが、間違いを自分で正すのに毎回役に立っていると思う。例えば“VT”など動 詞の時制の間違いを示すものなど。

\begin{tabular}{|l|l|l|l|l|l|l|}
\hline & 1 & 2 & 3 & 4 & 5 & \\
\hline Not at all & & & & & & Completely \\
\hline
\end{tabular}


4. To what extent do you agree with this statement: Written hints from the teacher (For example, "You are not using the correct verb tense") every time I make a mistake are helpful because they lead me to making corrections myself. / どの程度当てはまりま すか。:先生からの手書きのヒントが間違いを自分で正すの毎回役に立っていると思う。例え ば、“正しい時制をつかっていないですよ”など。

\begin{tabular}{|l|l|l|l|l|l|l|}
\hline & 1 & 2 & 3 & 4 & 5 & \\
\hline Not at all & & & & & & Completely \\
\hline
\end{tabular}

5. To what extent do you agree with this statement: It is helpful when the teacher underlines all of my mistakes because I can know it is a mistake and figure out how to correct it myself. / どの程度当てはまりますか:すべての間違いに下線が引いてあると間 違いを自分で見つけて正すのに役に立っていると思う。

\begin{tabular}{|l|l|l|l|l|l|l|}
\hline & 1 & 2 & 3 & 4 & 5 & \\
\hline Not at all & & & & & & Completely \\
\hline
\end{tabular}

6. To what extent do you agree with this statement: It is helpful when the teacher corrects my mistakes for me because I do not know how to correct them myself. / ぞ の程度当てはまりますか: どうやって間違いを正せばいいかわからないので、先生が間違いを 正しておいてくれる助かる。

\begin{tabular}{|l|l|l|l|l|l|l|}
\hline & 1 & 2 & 3 & 4 & 5 & \\
\hline Not at all & & & & & & Completely \\
\hline
\end{tabular}

7. To what extent do you agree with this statement: I continue to make similar grammar mistakes even if my teacher corrects me. / どの程度当てはまりますか: 先生か ら訂正されても同じような文法の間違いを繰り返してしまう。

\begin{tabular}{|l|l|l|l|l|l|l|}
\hline & 1 & 2 & 3 & 4 & 5 & \\
\hline Not at all & & & & & & Completely \\
\hline
\end{tabular}

\section{Appendix B}

Corrective Feedback Beliefs and Practices Survey (for Teachers)

A. How many years have you taught $\mathrm{L} 2$ writing?

$$
\begin{aligned}
& \text { - 1-2 years } \\
& \text { - 3-10 years } \\
& \text { - 10+ years }
\end{aligned}
$$

B. What context do you teach in?

- ESL (Students are living in an English-speaking country and need English to communicate)

- EFL (Students are not living in an English-speaking country)

C. What level of education have you completed (or in progress)?

- BA

- MA

- $\mathrm{PhD}$

D. What was/is your primary field of study for your degree? (i.e. Applied Linguistics, Literature, etc.)

E. In what level do you teach? (Multiple choice with standard descriptors and CEFR level scale)
- A1 (Beginner/Elementary)
- A2 (Pre-Intermediate)
- B1 (Intermediate)
- B2 (Upper Intermediate)
- C1 (Advanced) 
F. Which system(s) do you use to correct student writing? (Check all that apply)

- Indicate error has occurred and specify type of error with correction symbols

- Indicate error has occurred and give a written hint of how to correct it

- Indicate an error has occurred but do not specify the type

- Correct the error for the student.

- Directly tell the student about their writing.

- Other:

F2. (Optional) If you chose different systems, briefly explain the situations when you use them and rationale for using them.

G. How much class time do you spend explaining your feedback system?
- None
- $<10$ minutes
- 10-30 minutes
- 30-60 minutes
- $60+$ minutes

G2. (Optional) Briefly elaborate on what you do to explain your feedback system.

H. Do you feel that students understand and remember your feedback?

- Almost none of them understand

- Most students do not understand

- Some do and some do not

- Most students understand

- All students understand clearly
H2. (Optional) If you feel that they do not understand, why do you continue to use this method?

I. Do you have a document (e.g. correction symbols list) which you give to students that explains your corrective feedback system?

$$
\text { - Yes }
$$$$
\text { - No }
$$

12. If yes, what information does the document contain?

13. If no, why isn't a document provided?

J. Do you require students to produce a revised draft after you give them feedback?

$$
\text { - } \begin{aligned}
& \text { - } \\
& \text { - No }
\end{aligned}
$$

J2. If yes, is it graded and how much is it worth? Do you feel that it motivates students to revise their work?

J3. If no, do you feel that students check and review their comments anyway?

K. How much time does it take for you to correct one page of student work?
- $<5$ minutes
- 6-10 minutes
- 11-15 minutes
- 16-20 minutes
- 20+ minutes 
L. When you correct student work, how do you do so? (Check all that apply)

- On paper

- Verbally Face to Face

- Electronic Written Feedback

- Electronic Oral Feedback (Screencast)

L2. If you use different modalities for different types of tasks, please briefly explain.

M. How do you give feedback about content?

- Indicate a problem with content and specify type of problem with correction symbols

- Indicate a problem with content and give a written hint of how to rectify it

- Indicate a problem with content but do not specify what it is

- Directly tell the student what is missing or unclear

- Other:

M2. If you chose more than one method, briefly explain when you would use each method.

M3. Do you feel that students are able to take action on your corrections about content?

\begin{tabular}{|c|c|c|c|c|c|c|}
\hline & 1 & 2 & 3 & 4 & 5 & \\
\hline $\begin{array}{c}\text { Strongly } \\
\text { disagree }\end{array}$ & & & & & & $\begin{array}{c}\text { Strongly } \\
\text { agree }\end{array}$ \\
\hline
\end{tabular}

N. How do you give feedback about organization?

- Indicate a problem with organization and specify type of problem with correction symbols

- Indicate a problem with organization and give a written hint of how to rectify it
- Indicate a problem with organization but do not specify what it is

- Directly explain what the problem is

- Other:

N2. If you chose more than one method, briefly explain when you would use each method

N3. Do you feel that students are able to make corrections based on your feedback about organization?

\begin{tabular}{|c|l|l|l|l|l|l|}
\hline & 1 & 2 & 3 & 4 & 5 & \\
\hline $\begin{array}{c}\text { Strongly } \\
\text { disagree }\end{array}$ & & & & & $\begin{array}{c}\text { Strongly } \\
\text { agree }\end{array}$ \\
\hline
\end{tabular}

N4. Do you feel that it helps them to avoid similar problems in later pieces of writing?

\begin{tabular}{|c|c|c|c|c|c|c|}
\hline & 1 & 2 & 3 & 4 & 5 & \\
\hline $\begin{array}{c}\text { Strongly } \\
\text { disagree }\end{array}$ & & & & & & $\begin{array}{c}\text { Strongly } \\
\text { agree }\end{array}$ \\
\hline
\end{tabular}

O. How do you give feedback about vocabulary?

- Indicate error has occurred and specify type of error with correction symbols

- Indicate error has occurred and give a written hint of how to rectify it

- Indicate an error has occurred but do not specify the type

- Correct the error for the student.

- Other:

O2. If you chose more than one method, briefly explain when you would use each method. 
O3. Do you feel that students are able to make corrections based on your feedback about vocabulary?

\begin{tabular}{|c|c|c|c|c|c|c|}
\hline & 1 & 2 & 3 & 4 & 5 & \\
\hline $\begin{array}{c}\text { Strongly } \\
\text { disagree }\end{array}$ & & & & & & $\begin{array}{c}\text { Strongly } \\
\text { agree }\end{array}$ \\
\hline
\end{tabular}

O4. Do you feel that it helps them to avoid similar problems in later pieces of writing?

\begin{tabular}{|c|c|c|c|c|c|c|}
\hline & 1 & 2 & 3 & 4 & 5 & \\
\hline $\begin{array}{c}\text { Strongly } \\
\text { disagree }\end{array}$ & & & & & $\begin{array}{c}\text { Strongly } \\
\text { agree }\end{array}$ \\
\hline
\end{tabular}

P. How do you give feedback about grammar?

- Indicate error has occurred and specify type of error with correction symbols

- Indicate error has occurred and give a written hint of how to rectify it

- Indicate an error has occurred but do not specify the type

- Correct the error for the student.

- Other:

P2. If you chose more than one method, briefly explain when you would use each method.

P3. How likely do you feel that students are to make corrections based on your feedback about grammar?

\begin{tabular}{|c|c|c|c|c|c|c|}
\hline & 1 & 2 & 3 & 4 & 5 & \\
\hline $\begin{array}{c}\text { Strongly } \\
\text { disagree }\end{array}$ & & & & & & $\begin{array}{c}\text { Strongly } \\
\text { agree }\end{array}$ \\
\hline
\end{tabular}

Q. How many types of grammatical errors do you focus on when you grade a paper?

- $1-2$

- $3-4$
- 4-6
- 7-9
- All of them

Q1. If you do not give feedback about all grammatical errors, which errors do you give feedback about and why? 